\title{
ANALYSIS OF THE NUTRITIONAL STATUS OF CHILDREN AGED 10-13 YEARS IN THE SILESIAN PROVINCE, POLAND, AND CORRELATION WITH SOCIO-DEMOGRAPHIC FACTORS
}

\section{ANALIZA STOPNIA ODŻYWIENIA DZIECI W WIEKU 10-13 LAT W WOJEWÓDZTWIE ŚLĄSKIM, POLSKA, ORAZ JEGO KORELACJI Z CZYNNIKAMI SOCJODEMOGRAFICZNYMI}

\author{
Paweł Jonczyk ${ }^{1(A, B, C, D, E, F, G)}$, Magdalena Potempa-Jeziorowska ${ }^{1(A, B, C, D, E, F, G)}$, \\ Elżbieta Świętochowska ${ }^{2(A, D, E, G)}$, Marek Kucharzewski $^{1(\mathrm{~A}, \mathrm{D}, \mathrm{E}, \mathrm{G})}$
}

${ }^{1}$ Department of Descriptive and Topographic Anatomy, Faculty of Medical Sciences in Zabrze, Medical University of Silesia, Katowice, Poland

${ }^{2}$ Department of Medical and Molecular Biology, Faculty of Medical Sciences in Zabrze, Medical University of Silesia, Katowice, Poland

Authors' contribution Wkład autorów: A. Study design/planning zaplanowanie badań B. Data collection/entry zebranie danych C. Data analysis/statistics dane - analiza i statystyki D. Data interpretation interpretacja danych E. Preparation of manuscript przygotowanie artykułu F. Literature analysis/search wyszukiwanie i analiza literatury G. Funds collection zebranie funduszy
Tables: 11

Figures: 0

References: 24

Submitted: 2020 Dec 16

Accepted: $2021 \mathrm{Feb} 8$

\section{Summary}

Background. Nutritional disorders constitute a significant clinical problem in the 21st century. The problems of overweight and obesity concern not only adults, but are also increasingly affecting developing children.

Material and methods. The study was conducted among parents of children aged 10-13 years. Based on the data obtained from questionnaires distributed to the parents, body mass index (BMI) and degree of nutrition was determined and the influence of socio-demographic factors on the nutritional status of children was analyzed.

Results. This study found that approximately 16\% of children aged 10-13 are categorized as overweight, and $26 \%$ are categorized as obese. Place of residence has a significant effect on the BMI of included children, with those living in a country being characterized by a significantly lower BMI compared to those living in a town or city $(\mathrm{p}=0.008)$. Children whose parents are overweight or obese are characterized by a higher BMI compared to children whose parents are not overweight or obese $(\mathrm{p}=0.001)$.

Conclusions. This study shows that the presence of overweight or obesity in a parent is correlated with a higher BMI in their children. In addition, children living in the countryside have a significantly lower average BMI compared to children living in a town or city.

Keywords: obesity, malnutrition, socio-demographic factors, overweight, children nutrition

\section{Streszczenie}

Wprowadzenie. Zaburzenia stopnia odżywienia stanowią istotny problem kliniczny XXI wieku. Problem nadwagi i otyłości dotyczy nie tylko dorosłych, ale także coraz częściej dotyka rozwijajacych się dzieci.

Materiał i metody. Badanie prowadzone było wśród rodziców dzieci w wieku 10-13 lat. Na podstawie uzyskanych danych z kwestionariuszy ankiet dla rodziców obliczono wskaźniki masy ciała dzieci (ang. body mass index, BMI), określono stopień odżywienia oraz dokonano analizy wpływu czynników socjodemograficznych na stopień odżywienia dzieci.

Wyniki. W niniejszym opracowaniu udowodniono, że około $16 \%$ dzieci w wieku 10-13 lat boryka się z problemem nadwagi, $26 \%$ jest otyłych. Miejsce zamieszkania ma istotny wpływ na BMI badanych dzieci, przy czym osoby mieszkające na wsi charakteryzują się znacznie niższym BMI $\mathrm{w}$ porównaniu $\mathrm{z}$ mieszkającymi w mieście $(\mathrm{p}=0,008)$. Dzieci, których rodzice mają nadwagę lub otyłość, charakteryzują się wyższym BMI w porównaniu z dziećmi, których rodzice nie mają nadwagi lub otyłości $(p=0,001)$.

Wnioski. Udowodniono, że obecność nadwagi lub otyłości u rodzica jest skorelowana z wyższą wartością BMI u jego dzieci. Zaobserwowano również, że dzieci mieszkające na wsi charakteryzują się istotnie niższym BMI w porównaniu z dziećmi mieszkającymi w mieście.

Słowa kluczowe: otyłość, niedożywienie, czynniki socjodemograficzne, nadwaga, odżywianie dzieci 


\section{Introduction}

Overweight and obesity of the modern society, acclaimed as a " $21^{\text {st }}$ century epidemic", constitutes a complex health, economic and sociological problem. Nutritional disorders in the form of overweight and obesity more and more frequently concern not only adults, but also children and youths [1,2]. The societal perception of obesity has evolved over time. Not long ago, obesity was regarded as an indication of good material status and proper nutrition and was treated only as a cosmetic problem. Today there is no doubt that the struggle with overweight and obesity in children and youth has become one of the biggest challenges in the contemporary world [3].

The universal measure of overweight and obesity among adults is the body mass index (BMI), which is the quotient of body weight (expressed in kilograms) and the square of the height (expressed in meters). According to the World Health Organization (WHO), overweight in adults is diagnosed when the BMI is between 25 and $29.9 \mathrm{~kg} / \mathrm{m}^{2}$. Obesity is defined as follows:

- Class I obesity = BMI between 30 and $34.9 \mathrm{~kg} / \mathrm{m}^{2}$,

- Class II obesity = BMI between 35 and $39.9 \mathrm{~kg} / \mathrm{m}^{2}$,

- Class II obesity = BMI over $40 \mathrm{~kg} / \mathrm{m}^{2}$, also known as morbid obesity [1-3].

In the case of children and youths up until the age of 18 , due to the significant variation in BMI values in different developmental stages, the definition of overweight and obesity is based on percentile values of BMI. According to European standards, a child is defined as underweight if their BMI is below the $5^{\text {th }}$ percentile for a given population in terms of age and sex, overweight if their BMI is in the range of the 85-95 ${ }^{\text {th }}$ percentiles, and obese if their BMI is above the $95^{\text {th }}$ percentile [1]. Epidemiological research explicitly indicates that nutritional disorders are concerning younger and younger patients, both in developed and developing countries [1,2]. It is estimated that almost one in every five children living in Europe has an abnormal body weight [4]. Within the last thirty years, the number of obese children aged 2-5 and 12-19 years tripled, and quadrupled in the age group 6-11 years [5]. The highest frequency of overweight adolescents is found in Greece, where $28.9 \%$ of boys and $16.4 \%$ of girls are overweight or obese. In Italy, nearly $36 \%$ of 9 year old children are overweight or obese, and in Spain $26.6 \%$ of 9-13 year olds are overweight, with almost $4 \%$ being obese. Obesity in adolescents is much more frequent than obesity in children [4]. Scientific research among children and youths, who have been overweight or obese during the developmental period, excessive body weight and resulting health complications persists into adulthood in $80 \%$ [2]. The most frequent complications of overweight and obesity are metabolic disorders (e.g. diabetes and lipid metabolism disorders), increased risk of cardiovascular diseases, diseases of the musculoskeletal system, obstructive sleep apnea, bronchial asthma, and increased risk of neoplastic diseases [3,6]. The occurrence of overweight and obesity in children and youth is a complex phenomenon, which is significantly influenced by environmental, neurological, emotional, physiological, and genetic factors. Psychosocial conditionings and lifestyle may also play an important role, for example wealth, parental education, place of residence and dietary habits [7].

The objective of this study is to evaluate the type and prevalence of nutritional imbalances among selected children aged 10-13 and evaluate the potential influence of certain socio-demographic factors on the occurrence of overweight and obesity in the analyzed population.

\section{Material and methods}

The study was conducted in the years 2018-2019 in a group of parents of children aged 10-13 in selected primary schools in the Silesian Province, Poland, after obtaining the acceptance from school headmasters and parents. The Bioethical Committee of the Medical University of Silesia in Katowice issued approval (No. KNW/0022/ KB1/94/I/18/19) to conduct this medical research experiment. One thousand paper research questionnaires, containing 40 questions, with the option of selection of one or several responses, depending on the question, were distributed among eligible parents. The questions concerned anthropometric data, family structure, economic conditions, dietary habits and children's physical activity. The research questionnaire also collected data on the consumption frequency of meals by children, of food products and physical activity, which was designed based on available food frequency questionnaires (FFQ), prepared by the team of Behavioral Nutrition Conditions, Science Committee of Human Nutrition, Polish Academy of Science and from our own observations from the available medical literature. The survey questionnaires were filled in by the children's parents at parent-teacher meetings after preliminary instructions were delivered by the authors of the study. In total, 589 questionnaires were included in the statistical analysis. Inclusion criteria was surveys returned by parents of children in the 1013 age group, with questionnaires from parents of younger and older children excluded. Exclusion criteria were any incomplete questionnaires, questionnaires containing ambiguous answers, questionnaires from parents of children suffering from chronic diseases (including bronchial asthma, food intolerance, celiac disease, or 
hormonal disorders such as hypothyroidism and type I diabetes) and parents of children using drugs affecting metabolism (e.g. corticosteroids, thyroxine or insulin). The children analyzed comprised 304 girls (51.61\%), and 285 boys (48.39\%). The detailed characteristics of the research group are described in Table 1. Analysis of dependency between BMI of a given child and factors such as parental overweight/obesity and family structure was carried out. In addition, analysis of relations between a child's BMI and parental education and average income in a given household was carried out. Statistical analyses was conducted using IBM SPSS Statistics package, version 25. The package was used to calculate descriptive statistics as well as to conduct numerous incidence and comparative analyses using parametric Student's $t$ test for independent samples and for nonparametric tests; Mann-Whitney $U$ test and Kruskal-Wallis test. Correlation analysis was conducted using Pearson's $r$ coefficient, and Spearman's rho. A P-value of 0.05 was adopted as the significance level.

Table 1. Age and sex distribution of the study population

\begin{tabular}{|c|c|c|}
\hline Age group & Boys & Girls \\
\hline $\mathbf{1 0}$ & 116 & 116 \\
\hline $\mathbf{1 1}$ & 57 & 83 \\
\hline $\mathbf{1 2}$ & 76 & 70 \\
\hline $\mathbf{1 3}$ & 36 & 35 \\
\hline Total & 285 & 304 \\
\hline
\end{tabular}

\section{Results}

\section{Demographic data}

Nearly $88 \%$ of the respondents came from complete families, i.e. families with two biological parents, $11.66 \%$ were from single-parent families, and two children were under the care of a foster family. Most interviewed parents, $58.57 \%$, had two children, $19.02 \%$ had just one child, and approximately $22 \%$ were parents of a multichild family (defined as a family with three or more children). The average age of mothers participating in the study was $39.22 \pm 4.78$ years (range 28 to 55 years), and average age of fathers was $41.66 \pm 5.53$ years (range 27 to 65 years). Parental education level was varied, with most parents having attained secondary education; $39.39 \%$ of mothers and $40.10 \%$ of fathers. Higher education prevailed among mothers (42.26\%) and secondary education among fathers. Table 2 presents a breakdown of educational attainment of study participants. This correlates with the general population in Poland, where women often have a higher education level than men. Furthermore, the data indicates that $78.3 \%$ parents had a normal body weight, however $21.7 \%$ were overweight or obese.

Table 2. Education of parents

\begin{tabular}{|c|c|c|}
\hline Education & Mothers & Fathers \\
\hline Higher & $42.26 \%$ & $26.62 \%$ \\
\hline Secondary & $39.39 \%$ & $40.10 \%$ \\
\hline Vocational & $16.27 \%$ & $31.98 \%$ \\
\hline Lower secondary & $1.28 \%$ & $0 \%$ \\
\hline Primary & $0.80 \%$ & $1.30 \%$ \\
\hline
\end{tabular}

\section{The nutritional status of children}

Based on the anthropometric measurements and calculated BMI indexes, the nutritional status of included children was defined in accordance with European nomenclature. A child was defined as underweight if their BMI was below the $5^{\text {th }}$ percentile for a given population in terms of age and sex, overweight if their BMI was in the range of the $85-95^{\text {th }}$ percentiles, and obese if their BMI was over the $95^{\text {th }}$ percentile. Obesity concerned $26.35 \%$ of children in the study, with a further $16.44 \%$ of the population being defined as overweight. Malnutrition (defined in this study as BMI below 5th percentile - underweight) was revealed in $21.84 \%$ of included children. A normal body weight in relation to height and sex was noted in over $35 \%$ of children studied. The breakdown of nutritional status of the study population is presented in Table 3. We suspect that some girls aged 12-13 may have entered puberty, which is directly related to weight gain, sexual development and structural changes in the body. For this reason, some of the results in the above-mentioned group of girls regarding overweight and obesity may be slightly overestimated. This should be viewed as a limitation of our research results. 
Table 3. Nutritional status of children according to age

\begin{tabular}{|c|c|c|c|c|}
\hline \multirow{2}{*}{ Age } & \multicolumn{4}{|c|}{ Nutritional status } \\
\cline { 2 - 5 } & Obesity & Overweight & Normal weight & Malnutrition \\
\hline $\mathbf{1 0}$ & $25.43 \%$ & $13.79 \%$ & $49.57 \%$ & $11.21 \%$ \\
\hline $\mathbf{1 1}$ & $29.29 \%$ & $21.43 \%$ & $32.86 \%$ & $16.42 \%$ \\
\hline $\mathbf{1 2}$ & $25.34 \%$ & $16.44 \%$ & $29.45 \%$ & $28.77 \%$ \\
\hline $\mathbf{1 3}$ & $25.35 \%$ & $14.08 \%$ & $29.58 \%$ & $30.99 \%$ \\
\hline Total & $\mathbf{2 6 . 3 5 \%}$ & $\mathbf{1 6 . 4 4 \%}$ & $\mathbf{3 5 . 3 7 \%}$ & $\mathbf{2 1 . 8 4 \%}$ \\
\hline
\end{tabular}

\section{BMI of children depending on selected socio-demographic variables}

Non-parametric Mann-Whitney $U$ tests were conducted to determine if children aged 10-13 differed from one another in terms of BMI depending on if their parents were overweight or obese. In accordance with the results presented in Table 4, parental overweight/obesity is a significant factor in the determination of children's BMI. Children whose parents are overweight or obese are characterized by a higher BMI compared to children whose parents are not overweight or obese $(p=0.001)$.

Table 4. Children's BMI compared with parental overweight/obesity: mean results, standard deviation and significance of differences

\begin{tabular}{|c|c|c|c|c|c|c|c|}
\hline & \multicolumn{2}{|c|}{$\begin{array}{l}\text { Children of overweight or } \\
\text { obese parents } \\
{[n=126]}\end{array}$} & \multicolumn{2}{|c|}{$\begin{array}{c}\text { Children of parents who } \\
\text { are not overweight or } \\
\text { obese } \\
{[n=454]}\end{array}$} & \multirow[t]{2}{*}{$Z$} & \multirow[t]{2}{*}{$p$} & \multirow[t]{2}{*}{$r$} \\
\hline & $M$ & $S D$ & M & $S D$ & & & \\
\hline BMI & 19.78 & 4.16 & 17.87 & 3.15 & -4.73 & 0.001 & 0.14 \\
\hline
\end{tabular}

It was subsequently revealed that there are significant intersexual differences in the range of BMI observed in the analyzed group. The calculations were based on the parametric Student's $t$ test for independent samples. We may conclude, based on the obtained results, that sex is not a factor differentiating BMI in children aged 1013 (Table 5) ( $\mathrm{t}=-1.57 ; \mathrm{p}=0.116$; Cohen's $d=0.13$ ).

Table 5. Children's BMI compared with sex: mean results, standard deviation and significance of differences

\begin{tabular}{|c|c|c|c|c|c|c|c|c|c|}
\hline & \multicolumn{2}{|c|}{$\begin{array}{c}\text { Girls } \\
{[n=304]}\end{array}$} & \multicolumn{2}{|c|}{$\begin{array}{c}\text { Boys } \\
{[n=285]}\end{array}$} & \multirow{2}{*}{$t$} & \multirow{2}{*}{$p$} & \multicolumn{2}{|c|}{$95 \% C I$} & \multirow{2}{*}{$\begin{array}{c}\text { Cohen's } \\
d\end{array}$} \\
\hline & $M$ & $S D$ & $M$ & $S D$ & & & $L L$ & $U L$ & \\
\hline BMI & 18.09 & 3.33 & 18.54 & 3.64 & -1.57 & 0.116 & -1.02 & 0.12 & 0.13 \\
\hline
\end{tabular}

Subsequent analysis focused on exploring differences in BMI depending on place of residence (country, town or city) using the non-parametric Kruskal-Wallis test for calculations. Data presented in Table 6 indicates that place of residence has a significant effect on the BMI of included children, with those living in a country being characterized by a significantly lower BMI compared to those living in a town or city $(\mathrm{p}=0.008)$.

Table 6. Children's BMI compared with place of residence: mean results, standard deviation and significance of differences

\begin{tabular}{|c|c|c|c|c|c|c|c|c|c|}
\hline & $\begin{array}{c}\text { Children living in the } \\
\text { countryside } \\
{[\mathbf{n = 1 7 1 ]}}\end{array}$ & $\begin{array}{c}\text { Children living in } \\
\text { a town } \\
{[\mathbf{n = 1 0 1 ]}}\end{array}$ & \multicolumn{2}{c|}{$\begin{array}{c}\text { Children living in } \\
\text { a city } \\
{[\mathbf{n = 3 0 9 ]}}\end{array}$} & $\boldsymbol{H}$ & $\boldsymbol{p}$ & $\boldsymbol{E}^{\mathbf{2}}$ \\
\cline { 2 - 10 } & $\boldsymbol{M}$ & $\boldsymbol{S D}$ & $\boldsymbol{M}$ & $\boldsymbol{S D}$ & $\boldsymbol{M}$ & $\boldsymbol{S D}$ & & & \\
\hline BMI & 17.72 & 3.25 & 18.64 & 3.28 & 18.56 & 3.66 & 9.63 & 0.008 & 0.02 \\
\hline
\end{tabular}

The Kruskal-Wallis test was used to analyze if a child's BMI is dependent on the number of children in the family, which revealed that the number of children in a family is not a factor differentiating BMI level in children $(\mathrm{p}=0.636)$ (Table 7). 
Table 7. Children's BMI compared with the number of children in the family: mean results, standard deviation and significance of differences

\begin{tabular}{|c|c|c|c|c|c|c|c|c|c|}
\hline & \multicolumn{2}{|c|}{$\begin{array}{c}\text { One child in the } \\
\text { family } \\
{[n=112]}\end{array}$} & \multicolumn{2}{|c|}{$\begin{array}{c}\text { Two children in the } \\
\text { family } \\
{[n=345]}\end{array}$} & \multicolumn{2}{|c|}{$\begin{array}{c}\text { Three or more } \\
\text { children in the } \\
\text { family } \\
{[n=132]}\end{array}$} & \multirow[t]{2}{*}{$\boldsymbol{H}$} & \multirow[t]{2}{*}{$p$} & \multirow[t]{2}{*}{$E^{2}$} \\
\hline & $M$ & $S D$ & $M$ & $S D$ & $M$ & $S D$ & & & \\
\hline BMI & 18.60 & 3.38 & 18.23 & 3.66 & 18.24 & 3.09 & 0.91 & 0.636 & 0.01 \\
\hline
\end{tabular}

The non-parametric Mann-Whitney $U$ test was conducted to determine if family structure is a significant factor differentiating a child's BMI. The children staying in foster families were excluded from this analysis $(n=2)$. The results indicate that children being under care of two parents do not significantly differ in BMI from children coming from one-parent families ( $\mathrm{p}=0.19)$ (Table 8).

Table 8. Children's BMI compared with family structure: mean results, standard deviation and significance of differences

\begin{tabular}{|c|c|c|c|c|c|c|c|}
\hline & \multicolumn{2}{|c|}{$\begin{array}{l}\text { Children from a two- } \\
\text { parent family } \\
{[n=513]}\end{array}$} & \multicolumn{2}{|c|}{$\begin{array}{l}\text { Children from a single- } \\
\text { parent family } \\
{[n=68]}\end{array}$} & \multirow[t]{2}{*}{$Z$} & \multirow[t]{2}{*}{$p$} & \multirow[t]{2}{*}{$r$} \\
\hline & $M$ & $S D$ & $M$ & $S D$ & & & \\
\hline BMI & 18.26 & 3.44 & 18.69 & 3.83 & -1.31 & 0.190 & -0.05 \\
\hline
\end{tabular}

The non-parametric Kruskal-Wallis test was used to determine if a child's BMI is dependent on the type of work performed by their parents. The results show that the number of people in a family who work professionally, is not a factor differentiating BMI in children $(\mathrm{p}=0.395)$ (Table 9).

Table 9. Children's BMI compared with parental professional working status: mean results, standard deviation and significance

\begin{tabular}{|c|c|c|c|c|c|c|c|c|c|}
\hline & \multicolumn{2}{|c|}{$\begin{array}{l}\text { Children from } \\
\text { a family, in which } \\
\text { parents do not work } \\
\text { professionally } \\
{[n=13]}\end{array}$} & \multicolumn{2}{|c|}{$\begin{array}{c}\text { Children from } \\
\text { a family, in which } \\
\text { one parent works } \\
\text { professionally } \\
{[n=129]}\end{array}$} & \multicolumn{2}{|c|}{$\begin{array}{c}\text { Children from } \\
\text { a family, in which } \\
\text { both parents work } \\
\text { professionally } \\
{[n=443]}\end{array}$} & \multirow[t]{2}{*}{$\boldsymbol{H}$} & \multirow[t]{2}{*}{$p$} & \multirow[t]{2}{*}{$E^{2}$} \\
\hline & $M$ & $S D$ & $M$ & $S D$ & $M$ & $S D$ & & & \\
\hline BMI & 16.68 & 5.08 & 18.33 & 3.70 & 18.33 & 3.36 & 1.86 & 0.395 & 0.01 \\
\hline
\end{tabular}

Using By Spearman's rho correlation coefficient it was determined if parental education correlates with BMI of children. Calculations were performed separately to investigate potential relations of both the mother's and father's education with a child's BMI. The results of the analyses indicate that there is no statistically significant relationship between a child's BMI and parental education (neither mother's or father's) (Table 10).

Table 10. Children's BMI compared with mother's and father's education

\begin{tabular}{|l|c|c|}
\hline \multirow{2}{*}{ Mother's education } & Spearman's rho & BMI \\
\hline \multirow{3}{*}{ Father's education } & significance & 0.01 \\
\cline { 2 - 3 } & $\boldsymbol{n}$ & 572 \\
\cline { 2 - 3 } & Spearman's rho & -0.04 \\
\cline { 2 - 3 } & significance & 0.312 \\
\cline { 2 - 3 } & $\boldsymbol{n}$ & 563 \\
\hline
\end{tabular}

It was also investigated if a child's BMI is significantly correlated with average household income, which revealed there is no statistically significant relationship between household income and BMI of a child (Table 11). 
Table 11. Children's BMI compared with average income per capita in the household

\begin{tabular}{|c|c|c|}
\hline \multirow{2}{*}{ Average income per capita } & Spearman's rho & BMI \\
\cline { 2 - 3 } & significance & 0.03 \\
\cline { 2 - 3 } & $\boldsymbol{n}$ & 0.608 \\
\hline
\end{tabular}

\section{Discussion}

Childhood nutritional disorders in the form of overweight and obesity are frequently a family trait. It has been noted by experts that a child struggling with overweight or obesity problems tends to visit the doctor with an overweight or obese mother or father, and often also with overweight or obese siblings. It has been shown that the probability of a child having a body weight disorder increases 4-5 times if one parent is obese. Where both parents are obese, the risk increases 13-fold [4].

According to Maffeis et al. obesity in the mother is a more influential factor for excess body weight in a child than obesity in the father [8]. Lake et al. stated that the average BMI increases with a child's age [9], and increases are highest in cases of children where both parents are obese [10,11]. Mazur et al. pointed out that obesity of one or both parents increases the risk of overweight and obesity problems in their offspring 3.33-5.98 times [11]. In addition, a large epidemiological study conducted in Poland in the years 2015-2017, "COSI (Childhood Obesity Surveillance Initiative) Project", showed that in a population of children aged 8, who were overweight or obese, almost half of their mothers and approximately one third of their fathers also had a problem with excessive body weight. This relationship was found to be statistically significant both girls and boys [12].

Trzcińska et al. indicated that the abnormal body weight is more likely to occur in children coming from a city. The incidence of overweight children from a city exceeded $9 \%$, compared with the incidence of overweight children from a rural community which was only 7.5\%. Obesity has been observed, however, over twice as often in boys living in the country (almost 9\%) compared to boys living in urban areas (almost 4\%). Normal body weight has been found more frequently in girls in an urban community, and overweight and obesity more often in girls in a rural community [13]. Rogalska-Niedźwiedź et al. conducted research on four year old children and indicated that obesity is diagnosed more frequently in children living in the country [14]. In other available studies, results point to a comparable universality of overweight and obese children both living in the country and in the city [15-17].

Guven et al. reported that obese children, more often that children with normal body weight, have parents with only primary education [18]. Falkowska et al. demonstrated in their research that about $12 \%$ of children's mothers with normal and excessive body weight had primary education, however $13.1 \%$ of girls and $14.3 \%$ of boys with normal body weight and about $16 \%$ of girls and boys with excessive body weight had a father with primary education, however these differences did not reach statistical significance. Furthermore, it has been shown that approximately $50 \%$ of girls and approximately $47 \%$ of boys with normal body weight and $50 \%$ of girls and approximately $44 \%$ of boys with excessive body weight had two parents with secondary education, however again this was not statistically significant. Having a mother with higher education was noted in $37 \%$ of girls and $41 \%$ of boys with normal body weight and in $37.2 \%$ of girls and $45.2 \%$ of boys with excessive body weight; and having a father with higher education was noted in $30.1 \%$ of girls and $38 \%$ of boys with normal body weight and $33 \%$ of girls and $39 \%$ of boys with excessive body weight, however all of these differences were statistically insignificant [19]. Parizkova in her analyses stated a rarer incidence of the occurrence of overweight and obesity in children, whose parents were educated to a higher level [20]. On the other hand, Shrewsbury and Wardle indicated that a mother's education level does not influence the development of childhood obesity [21]. In accordance with the report by Olszanecka-Glinianowicz et al. it was shown that there is a higher risk of developing obesity in children aged 7-9 living in Silesian Province (Poland) if the father was obese [22].

Findings from Rogalska-Niedźwiedź et al. indicated that obesity more often concerns only children [14]. Falkowska et al. stated however, that approximately $66 \%$ of girls and boys with normal body weight and $58.4 \%$ of girls and $65.2 \%$ of boys with excessive body weight have two or fewer siblings. In terms of one-child families, $21 \%$ of girls and about $23 \%$ of boys with normal body weight did not have any siblings and $22.1 \%$ of girls and $26 \%$ of boys with excessive body weight did not have any siblings. Having 3-4 siblings was declared by approximately $10 \%$ of girls and boys with normal body weight and $12.4 \%$ of girls and $8.7 \%$ of boys with excessive body weight. Interestingly, overweight and obese boys did not have such numerous siblings. However, no statistically significant correlations have been found between the number of siblings and nutritional status of the analyzed children [19]. 
Tabak and coworkers indicated that overweight occurred more frequently in youths living in single-parent families than in two-parent families (30.2\% vs. 19.5\%; $\mathrm{p}=0.049)$. There was a higher incidence of overweight youths observed in families whose structure changed within the first 13 years of the child's life for example due to a parent's death or divorce, and in fact the risk of becoming overweight in these children was twice that of two-parent families. Youths from families whose economic status got worse (due to changes in family structure) were twice as likely to become overweight than their peers in families with average or high economic status $(\mathrm{p}=0.057)[23]$.

The formation of children's eating habits is multifactorial. Leaving aside genetic considerations and diseases that cause eating disorders in children, it appears that epigenetic considerations are most important. The role of children's parents and guardians is to educate their offspring regarding principles of rational nutrition, promote healthy eating behaviors and physical activity from early childhood. It has been shown that appropriate eating habits are formed in infancy and early childhood, which not only influence the child's development in a given period of life, but also influence the development of diet-related diseases into adulthood [24].

\section{Conclusions}

Childhood nutritional disorders occurring at school age, both in the form of excessive body weight in relation to their age and sex (overweight and obesity), as well as insufficient body weight, or malnutrition, constitute significant medical, psychosocial and economic problems in the contemporary world. This study has indicated that due to hyperalimentation, over $43 \%$ of children struggle with the problem of overweight and obesity $(16.44 \%$ of all examined children were overweight and $26.35 \%$ were obese). Interestingly, increased BMI in children is not statistically significantly related to factors such as the child's sex, number of offspring in the family, the family structure, number of professionally active people in the family, income per family member or parents' education. It was shown, however, that the presence of overweight or obesity in a parent is correlated with higher BMI in their children. It was observed as well that the children living in the country are characterized by a significantly lower BMI compared to the children living in a town or in a city. It therefore appears that making parents and children aware of the health risks resulting from overweight and obesity as well as malnutrition is essential for contemporary society. Only early prevention of nutritional disorders and care about proper development of children will guarantee children have a healthy start to adult life.

\section{Disclosures and acknowledgements}

Ethical approval and consent to participate in this medical research experiment was obtained from The Bioethical Committee of the Medical University of Silesia in Katowice (resolution No. KNW/0022/ KB1/94/I/18/19). The study participants gave their written consent to participate in the study, as recommended by the Bioethics Committee.

The oral consent of the study participants was obtained for publication of the results, as agreed by the Bioethics Committee. The authors of the publication also gave verbal consent to publish the work in the Journal.

\section{References:}

1. Barczyk A, Kutkowska-Kaźmierczak A, Castañeda J, Obersztyn E. The genetics of obesity - pathogenetic, clinical and diagnostic aspects. Dev Period Med. 2017; 21: 186-202.

2. Banaś I. [Obese children - obese adults]. Lek w Polsce. 2014; 24: 5-60 (in Polish).

3. Gawlik A, Zachurzok-Buczyńska A, Małecka-Tendera E. Complications of obesity in children and adolescents. Endocrionology, Obesity and Metabolic Disorders. 2009; 5: 19-27.

4. Drewa A, Zorena K. Prevention of overweight and obesity in children and adolescents in European countries. Pediatr Endocrinol Diabetes Metab. 2017; 23(3): 152-158. https://doi.org/10.18544/PEDM-23.03.0087

5. Daniels SR, Jacobson MS, McCrindle BW, Eckel RH, Sanner BM. American Heart Association Childhood Obesity Research Summit: executive summary. Circulation. 2009; 119(15): 2114-23. https://doi.org/10.1161/CIRCULATIONAHA.109.192215

6. Arisaka O, Ichikawa G, Koyama S, Sairenchi T. Childhood obesity: rapid weight gain in early childhood and subsequent cardiometabolic risk. Clin Pediatr Endocrinol. 2020; 29(4): 135-142. https://doi.org/10.1297/cpe.29.135

7. Kupczak-Wiśniowska B, Borgosz J, Podsiadło B, Serzysko B, Jędrkiewicz B. [Obesity in children - a problem of the contemporary civilization]. Nursing in the 21st Century 2017; 16(1): 44-50 (in Polish). https://doi.org/10.1515/pielxxiw-2017-0007 
8. Ligenza I, Jakubowska-Pietkiewicz E, Łupińska A, Jastrzębska A, Chlebna-Skokół D. Estimation of interdependence of environmental factors and body mass excess among children in the kindergarten-age. Pediatr. Endocrinol. 2011; 2(35): 25-32.

9. Lake JK, Power C, Cole TJ. Child to adult body mass index in the 1958: British birth cohort: associations with parental obesity. Arch Dis Child. 1997; 77: 376-381. https://doi.org/10.1136/adc.77.5.376

10. Bryl W, Hoffmann K, Miczke A, Pupek-Musialki D. [Obesity of children and adolescents - epidemiology, consequences and prevention]. Przew Lek. 2006; 9: 91-95 (in Polish).

11. Mazur A, Klimek K, Małecka-Tendera E. [Obesity at a young age - epidemiology, health aftermaths, necessity of prevention. Risk factors of obesity in school children from Subcarpathian Region]. Endocrinology, Obesity and Metabolic Disorders. 2011; 7: 157-166 (in Polish).

12. Fijałkowska A, Oblacińska A, Stalmach M. Overweight and obesity in 8-year-old children considering biological, behavioural and social conditions. European Childhood Obesity Surveillance Initiative (COSI). IMID: Warszawa; 2017.

13. Trzcińska D, Świderska D, Tabor P, Olszewska E. [Excess weight and obesity in 6-year-old children from urban and rural areas]. Rocznik Lubuski. 2014; 40: 189-200 (in Polish).

14. Rogalska-Niedźwiedź M, Charzewska J, Wajszczyk B, Chwojnowska Z, Chabros E, Fabiszewska J, et al. Overweight and obesity in four-year-old children. In: Charzewska J, Bergman P, Kaczanowski K, Piechaczek H., editors. Obesity as the epidemic of 21st century. Warszawa: Akademia Wychowania Fizycznego w Warszawie; 2006.

15. Grohold EK, Stigum H, Nordhagen R. Overweight and obesity among adolescents in Norway: cultural and socio-economic differences. Journal of Public Health. 2008; 30(3): 258-265. https://doi.org/10.1093/pubmed/fdn037

16. Popławska H, Dmitruk A, Czeczuk A. [Overweight and obesity incidence in rural girls and boys depending on their parents' education level]. Zdr. Publ .2007; 117(1): 54-58 (in Polish).

17. Jonczyk P, Potempa M, Kajdaniuk D. Level of nutrition and nutrition disorders as well as characteristics of dietary habits and physical activity among 6-13-year-old children attending selected primary schools in Opole and Silesian Provinces in Poland. Pediatr Med Rodz. 2016; 12(2): 177-193. https://doi.org/10.15557/PiMR.2016.0018

18. Güven A, Odaci H, Ozgen IT, Bek Y. Effects of individual factors on adolescent obesity: study in Turkey. Pediatr Int. 2008; 50(3): 356-362. https://doi.org/10.1111/j.1442-200X.2008.02585.x

19. Falkowska A, Stefańska E, Ostrowska L. [The evaluation of children's nutrition aged 10-12 with differentiated nutritional state]. Endocrinology, Obesity and Metabolic Disorders. 2011; 7: 222-228 (in Polish).

20. Parizkova J. Impact of education on food behaviour, body composition and physical fitness in children. Br. J. Nutr. 2008; 99(S1): 26-32. https://doi.org/10.1017/S0007114508892483

21. Shrewsbury V, Wardle J. Socioeconomic status and adiposity in childhood: a systematic review of crosssectional studies 1990-2005. Obesity. 2008; 16(2): 275-284. https://doi.org/10.1038/oby.2007.35

22. Olszanecka-Glinianowicz M, Małecka-Tendera E, Klimek K, Matusik P, Żak-Gołąb A. [Risk factors of simple obesity in 7-9 year-old Silesian children]. Endocrinol. Pediatr. 2006; 2: 31-38 (in Polish).

23. Tabak I, Oblacińska A, Jodkowska M, Mikiel-Kostyra K. [Changes in structure and socioeconomic position of the family as determinants of overweight in adolescents]. Pediatr Endocrinol Diabetes Metab. 2012; 18(2): 70-75 (in Polish).

24. Erdélyi-Sipos A, Badacsonyiné Kassai K, Kubányi J, Szűcs Z, Biró L, Raposa LB. [Nutrition assessment of 0-3-year-old infants and toddlers with particular focus on macro- and micronutrient intake]. Orv Hetil. 2019; 160(50): 1990-1998 (in Hungarian). https://doi.org/10.1556/650.2019.31585 